\title{
Oxidation of L-thiazolidine-4-carboxylate by L-proline dehydrogenase in Escherichia coli
}

\author{
Charles E. Deutch* \\ Department of Biological Sciences, University of Nevada, Las Vegas, 4505 Maryland Parkway, \\ Las Vegas, Nevada 89154, USA
}

(Received 14 October 1991; revised 3 March 1992; accepted 7 May 1992)

\begin{abstract}
L-Thiazolidine-4-carboxylate (T4C, $\gamma$-thioproline) is a toxic analogue of L-proline. T4C can be oxidized by Escherichia coli to form $\boldsymbol{N}$-formylcysteine, which is hydrolysed to yield formate and cysteine. To determine if L-proline dehydrogenase (EC 1.5.99.8) catalyses T4C degradation, membrane fractions from $E$. coli were tested for $\mathrm{T} 4 \mathrm{C}$ and proline oxidation activity. The specific activity for $\mathrm{T} 4 \mathrm{C}$ oxidation in membranes from bacteria grown with 10 mM-proline was similar to the specific activity for proline oxidation and about 100 times that in membranes from bacteria grown without proline. Both oxidation activities were inactivated at $45{ }^{\circ} \mathrm{C}$ at the same rate. Membranes from a strain with a deletion of the put $A$ gene encoding L-proline dehydrogenase or a strain with a put $A$ :: Tn5 insertion mutation had no detectable activity with either substrate. Although T4C was a simple competitive inhibitor of proline oxidation, proline inhibited $\mathrm{T4C}$ oxidation in a way that gave competitive but sigmoidal kinetics. At low concentrations, $\mathrm{T} 4 \mathrm{C}$ induced proline dehydrogenase synthesis. Cysteine auxotrophs containing the put $A:: \mathrm{Tn} 5$ mutation could still use $\mathrm{T} 4 \mathrm{C}$ as a cysteine source, and bacteria with this mutation consumed oxygen in the presence of $\mathrm{T} 4 \mathrm{C}$ at half the control rate. These results indicate that $\mathrm{T} 4 \mathrm{C}$ is a substrate and an inducer of L-proline dehydrogenase but suggest that $E$. coli also contains a second enzyme catalysing T4C degradation.
\end{abstract}

\section{Introduction}

Toxic analogues are often used in studies of amino acid uptake and metabolism in micro-organisms (Fowden et al., 1967). L-Thiazolidine-4-carboxylate (T4C, $\gamma$-thioproline) is a sulphur-containing proline analogue that is a therapeutic agent for some tumours (Brugarolas \& Gosalvez, 1980; Hahn, 1980) and a scavenging agent for reactive nitrosamines (Tsuda et al., 1988; Miwa et al., 1989). Although rarely used for bacterial studies, T4C inhibits the growth of Escherichia coli (Unger \& DeMoss, $1966 a$ ). It competes with proline for uptake by the major proline carrier (Roland \& Tristram, 1975) and for aminoacylation by prolyl-tRNA synthetase (Papas \& Mehler, 1970; Busiello et al., 1979).

T4C is oxidized by whole cells of $E$. coli (Unger \& DeMoss, 1966 b) and by mitochondria from rat liver (Cavallini et al., 1956; Mackenzie \& Harris, 1957; Johnson \& Strecker, 1962) and barley (Elthon \& Stewart,

* Tel. (702) 5974421 ; fax (702) 7393956.

Abbreviation: T4C, L-thiazolidine-4-carboxylate ( $\gamma$-thioproline).
1984). The degradative pathway in mitochondria is similar to that for proline (Fig. 1). T4C is first converted to 2,3-thiazoline-4-carboxylate; ring opening yields $N$-formylcysteine, which then is cleaved to give formate and cysteine (Cavallini et al., 1956; Mackenzie \& Harris, 1957). The initial oxidation of T4C in mitochondria is catalysed by L-proline dehydrogenase [L-proline : (acceptor) oxidoreductase; EC 1.5.99.8]; hydrolysis of $\mathrm{N}$-formylcysteine in liver is due to a second cytosolic enzyme (Boehler et al., 1989).

Unger \& DeMoss (1966b) concluded that L-proline dehydrogenase was not involved in T4C degradation in $E$. coli because oxidation was detected in cells grown without proline or T4C. Proline dehydrogenase activity in $E$. coli and Salmonella typhimurium is known now to be contained in a multifunctional protein encoded by the putA gene (Ratzkin \& Roth, 1978; Menzel \& Roth, $1981 a$ ). The PutA protein is a dimeric peripheral membrane protein that oxidizes proline and $\Delta 1$-pyrroline-5-carboxylate and transfers electrons to the aerobic electron transport chain (Scarpulla \& Soffer, 1978; Menzel \& Roth, $1981 a$; Abrahamson et al., 1983). PutA also occurs in the cytoplasm where it binds to DNA and 


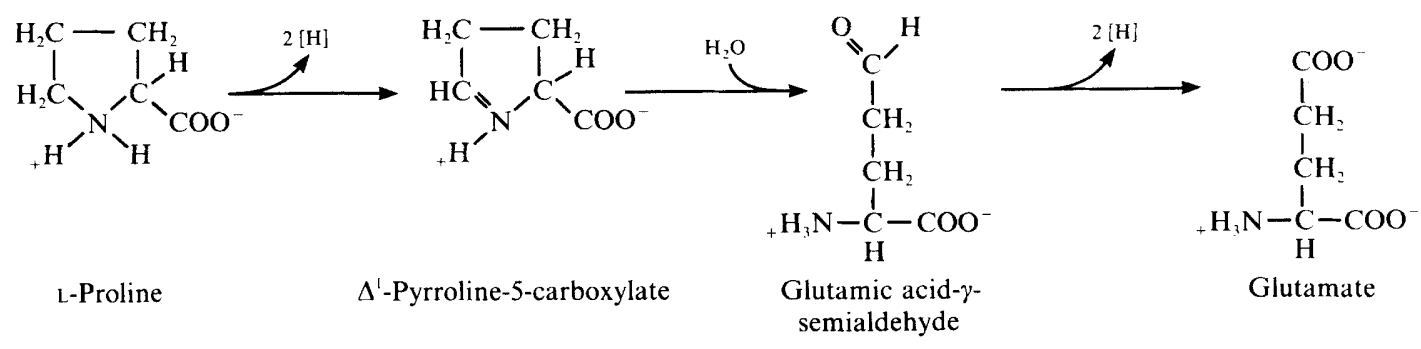<smiles>CC(C)[C@H]1C[C@@H](C)[C@@H]1C(=O)[O-]</smiles>

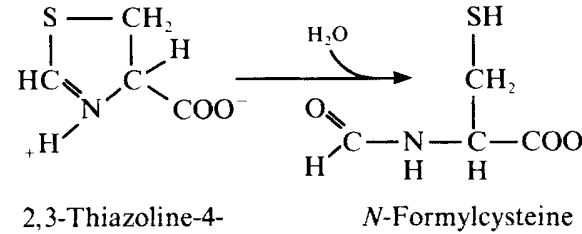
carboxylate

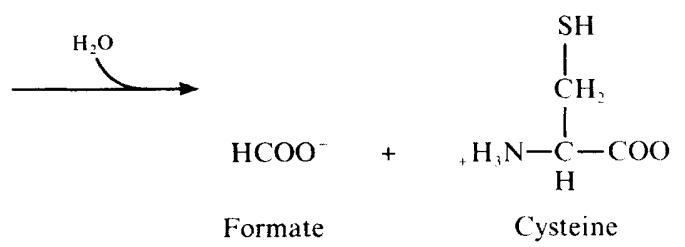

Fig. 1. Pathways of proline and $\mathrm{T} 4 \mathrm{C}$ degradation. regulates transcription of putA and the adjacent putP gene for the major proline carrier (Menzel \& Roth, $1981 b$; Ostrovsky de Spicer et al., 1991). Transcription of these genes is induced by proline (Dendinger \& Brill, 1970; Maloy \& Roth, 1983). I have re-examined the relationship between proline dehydrogenase and $\mathrm{T} 4 \mathrm{C}$ oxidation and demonstrated that this enzyme is partly responsible for T4C degradation.

\section{Methods}

Bacterial strains. E. coli K12 strains CSH4 (thi trp lacZ rpsL), JT31 (thi trp lac $Z$ rpsL putA1 ::Tn5), JT34 (thi trp lac $Z$ rpsL putP3::Tn5) and RM2 (thi trp lacZ rpsL $\triangle$ putPA101) were obtained from Dr Janet Wood of the University of Guelph, Canada. Strains JM15 (cysE50 tfr8) and JM96 (cysH56 thr-l leuB6 trp-1 hisGI argHI thi-1 ara-13 lac Yl gal-6 malA1 xyl-1 mtl-1 strA9 tonA2 supE44 $\left.\lambda^{-}\right)$were provided by $\mathrm{Dr}$ Barbara Bachmann of Yale University, CT, USA. The putA1::Tn5 mutation in strain JT31 was moved into the cysteine auxotrophs by Plkc transduction (Curtiss, 1981). Kanamycin-resistant colonies were selected on LB agar (Miller, 1972) containing $25 \mu \mathrm{g}$ kanamycin $\mathrm{ml}^{-1}$, and tested on put-indicator medium (Menzel \& Roth, 1981b)

Growth conditions. Bacteria were grown aerobically at $37^{\circ} \mathrm{C}$ in minimal Medium A containing $0.5 \%(\mathrm{v} / \mathrm{v})$ glycerol as previously described (Deutch et al., 1985, 1989). L-Proline, L-thiazolidine-4carboxylate (Sigma) and other supplements were added as specified. Radial streak tests for inhibition of growth by $\mathrm{T} 4 \mathrm{C}$ were done as described by Wood (1981).

Preparation of membrane fractions. Membrane fractions were prepared from exponential-phase cells by the method of Abrahamson et al. (1983) and stored in small aliquots at $-80^{\circ} \mathrm{C}$. Membranes were thawed prior to each experiment and used only once.

Identification of products. Membranes $(50 \mu \mathrm{l})$ from strain CSH4 grown with $10 \mathrm{mM}$-L-proline were combined with $50 \mu 10 \cdot 1 \mathrm{M}-\mathrm{T} 4 \mathrm{C}$ and $150 \mu \mathrm{l}$ of Buffer B (10 mM-MOPS, pH 7.5, $20 \mathrm{~mm}-\mathrm{MgCl}_{2}, 10 \%, \mathrm{v} / \mathrm{v}$, glycerol). After incubation at $37^{\circ} \mathrm{C}$ for various times, the reaction mixtures were heated in boiling water for $2 \mathrm{~min}$ and insoluble material was removed by centrifugation at 10000 r.p.m. for $10 \mathrm{~min}$ in a TOMY microcentrifuge. Supernatant fractions were spotted on $20 \times 20 \mathrm{~cm}$ squares of Whatman $3 \mathrm{MM}$ paper along with standards, and the chromatograms developed in phenol/water $(80: 20, \mathrm{v} / \mathrm{v})$. The chromatograms were dried overnight and dipped in acetone/ether $(1: 1, \mathrm{v} / \mathrm{v})$. They were sprayed with $0.3 \%(\mathrm{w} / \mathrm{v})$ ninhydrin in acetone and heated at $100^{\circ} \mathrm{C}$ to reveal amino acids, or sprayed with $4,4^{\prime}$-bis(dimethylamino)diphenylcarbinol (BDC-OH) reagent (Burt et al., 1976) to detect compounds with thiol or carboxylic acid groups.

Thiazolidine-4-carboxylate oxidation assays. Aliquots of membranes $(10-50 \mu \mathrm{l})$ were combined with Buffer B to a volume of $0.9 \mathrm{ml}$ in $1.5 \mathrm{ml}$ microcentrifuge tubes. After equilibration to $37^{\circ} \mathrm{C}, 0.1 \mathrm{ml}$ of $0 \cdot 1 \mathrm{M}$-T4C was added to each tube. After various times, the reactions were stopped with $0.1 \mathrm{ml} 50 \%(\mathrm{w} / \mathrm{v})$ trichloroacetic acid; insoluble material was removed by centrifugation for $10 \mathrm{~min}$ at 10000 r.p.m. in a TOMY microcentrifuge, and the cysteine content of each supernatant fraction was determined by the method of Gaitonde (1967). Duplicate $0.1 \mathrm{ml}$ aliquots were combined with water to a volume of $0.5 \mathrm{ml} ; 0.5 \mathrm{ml}$ glacial acetic acid and $0.5 \mathrm{ml}$ acidic ninhydrin reagent $(250 \mathrm{mg}$ ninhydrin in a mixture of $6 \mathrm{ml}$ acetic acid and $4 \mathrm{ml} \mathrm{HCl}$ ) were added to each tube. After heating the tubes at $100{ }^{\circ} \mathrm{C}$ for $10 \mathrm{~min}$ and cooling them in water, $3.5 \mathrm{ml} 95 \%$ ethanol was added to each tube and the absorbances at $560 \mathrm{~nm}$ measured in a Shimadzu $160 \mathrm{U}$ spectrophotometer. Cysteine contents were determined from a L-cysteine standard curve. Assays of a particular preparation were reproducible $\pm 10 \%$. An activity unit was defined as the formation of $1 \mathrm{nmol}$ cysteine equivalents $\mathrm{min}^{-1}$.

Oxygen uptake studies. Exponential-phase bacteria were harvested, suspended in Medium A without a carbon source, and incubated at $37^{\circ} \mathrm{C}$ for $60 \mathrm{~min}$ to reduce endogenous substrates. A $2.7 \mathrm{ml}$ volume of each suspension was combined with $0.3 \mathrm{ml}$ of $0 \cdot 1 \mathrm{M}$-substrate solution and equilibrated to $25^{\circ} \mathrm{C}$; oxygen uptake was measured with a Clarktype electrode connected to a monitor (Yellow Springs Instruments, model 5300) and a recorder (Kipp and Zonen, model B41). Assays were reproducible $\pm 10 \%$ for a particular culture. Substrate-dependent rates of oxygen uptake were calculated by subtracting the rate without added substrate. 
Other assays. Proline dehydrogenase activity in toluene-treated whole cells was determined as described previously (Deutch et al., 1985). Assays of a particular culture were reproducible $\pm 15 \%$. Proline dehydrogenase activity in membrane fractions was measured at room temperature using $o$-aminobenzaldehyde (Abrahamson et al., 1983). Assays of a particular preparation were reproducible $\pm 10 \%$. Protein concentrations were determined by the Lowry method using bovine serum albumin as the standard.

\section{Results}

Spectrophotometric assay of T4C oxidation in membrane fractions

In previous studies (Mackenzie \& Harris, 1957; Unger \& DeMoss, 1966 b; Elthon \& Stewart, 1984), oxidation of T4C by intact bacteria or mitochondria was measured manometrically as oxygen uptake. To determine if T4C degradation in $E$. coli is mediated by the membraneassociated enzyme proline dehydrogenase, a spectrophotometric assay for T4C catabolism was developed. Attempts to measure T4C oxidation by reduction of 2,6dichlorophenolindophenol (Abrahamson et al., 1983) or $p$-iodonitrotetrazolium (Scarpulla \& Soffer, 1978) were unsuccessful, so an assay based on product formation was used. The degradative pathway in Fig. 1 was confirmed for $E$. coli by combining T4C with membranes from strain CSH4 (put $A^{+}$) grown with $10 \mathrm{mM}$-L-proline. When the reaction mixtures were analysed by paper chromatography, T4C $\left(R_{\mathrm{F}} 0 \cdot 76\right)$, a small amount of cysteine $\left(R_{\mathrm{F}} 0.63\right)$, and a product with an $R_{\mathrm{F}}$ of 0.55 were observed. The latter spot reacted with the BDC-OH reagent for thiols but not with ninhydrin; it was absent in mixtures stopped at $0 \mathrm{~min}$ and easily distinguished from cystine $\left(R_{\mathrm{F}} 0 \cdot 32\right)$. When samples containing the product were acidified and heated, the compound disappeared and the cysteine spot intensified. Although efforts to synthesize $N$-formylcysteine (Mackenzie \& Harris, 1957) were unsuccessful, the fact that the reaction product reacted with a thiol reagent but not with ninhydrin and was hydrolysed to give cysteine suggested it was this intermediate.
To measure $\mathrm{T} 4 \mathrm{C}$ degradation quantitatively, $\mathrm{T} 4 \mathrm{C}$ and membrane fractions were combined, incubated at $37^{\circ} \mathrm{C}$ for various times, and the reactions stopped with acid. Aliquots of the acid-soluble material were mixed with the acidic ninhydrin reagent of Gaitonde (1967) and heated. This resulted simultaneously in the conversion of $\mathrm{N}$ formylcysteine to cysteine and in the reaction of cysteine with ninhydrin to form a pink product with an absorbance maximum at $560 \mathrm{~nm}$. T4C reacted with the acidic ninhydrin to form an orange product with a maximum absorbance at $430 \mathrm{~nm}$ and a small absorbance at $560 \mathrm{~nm}$; T4C also showed some spontaneous hydrolysis to cysteine. However, using control mixtures lacking membranes and stopped at the same time-points, T4C oxidation could be measured quantitatively. Cysteine formation was linear for $20 \mathrm{~min}$ and proportional to the amount of membranes up to $500 \mu \mathrm{g}$ protein.

Degradation of $\mathrm{T} 4 \mathrm{C}$ by membrane fractions was similar to membrane-dependent proline oxidation (Abrahamson et al., 1983). Oxidation required intact membranes containing a functional electron transport chain. Formation of cysteine from T4C was inhibited completely by detergents $(0 \cdot 1 \%$ Tween 20 , Brij 58 , Triton $\mathrm{X}-100$ or SDS). KCN (10 mM) abolished T4C oxidation completely and sodium azide $(100 \mathrm{~mm})$ reduced it by $60 \% . \mathrm{NaCl}(1.0 \mathrm{M})$ or $\mathrm{KCl}(1.0 \mathrm{M})$ completely inhibited T4C oxidation and $1.0 \mathrm{M}-\left(\mathrm{NH}_{4}\right)_{2} \mathrm{SO}_{4}$ reduced it by more than $60 \%$. When membrane fractions from strain CSH4 were heated at $45^{\circ} \mathrm{C}$, there was a simultaneous and nearly linear inactivation of both activities.

\section{Genetic analysis of T4C oxidation}

Membrane fractions from wild-type bacteria and several put mutants were tested for $\mathrm{T} 4 \mathrm{C}$ and proline oxidation (Table 1). Membranes from strain CSH4 (put $A^{+}$) grown without proline contained low levels of both activities, while membranes from bacteria grown with $10 \mathrm{~mm}$ proline contained about 100 -fold higher activity with each substrate. The mean specific activity for T4C oxidation at $37^{\circ} \mathrm{C}$ in five equivalent preparations was $88.2 \pm 11.1 \mathrm{nmol} \mathrm{min}^{-1}(\mathrm{mg} \text { protein })^{-1}$. The mean

Table 1. Specific activities of T4C and proline oxidation in membrane fractions from E. coli CSH4 and derivatives

\begin{tabular}{|c|c|c|c|c|c|}
\hline Strain & $\begin{array}{l}\text { Relevant } \\
\text { genotype }\end{array}$ & $\begin{array}{l}\text { Growth } \\
\text { conditions }\end{array}$ & $\begin{array}{l}\text { No. of } \\
\text { expts }\end{array}$ & $\begin{array}{c}\text { T4C oxidation } \\
{\left[\text { nmol } \min ^{-1}(\text { mg protein })^{-1}, 37^{\circ} \mathrm{C}\right]}\end{array}$ & 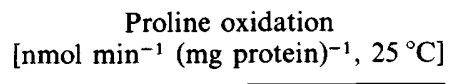 \\
\hline CSH 4 & $p u r A^{+} p u t P^{+}$ & $\begin{array}{l}\text { - Proline } \\
+ \text { Proline }\end{array}$ & $\begin{array}{l}3 \\
5\end{array}$ & $\begin{array}{c}0 \cdot 6 \pm 0 \cdot 3 \\
88 \cdot 2 \pm 11 \cdot 1\end{array}$ & $\begin{array}{r}0 \cdot 4 \pm 0 \cdot 4 \\
35 \cdot 2 \pm 4 \cdot 1\end{array}$ \\
\hline JT31 & putAl:: $\operatorname{Tn} 5$ & + Proline & 2 & $<0.2$ & $<0.2$ \\
\hline RM2 & $\Delta(p u t P A 101)$ & + Proline & 2 & $<0 \cdot 2$ & $<0.2$ \\
\hline JT34 & putP3:: $\operatorname{Tn} 5$ & + Proline & 3 & $64.0 \pm 17.6$ & $25 \cdot 1 \pm 9 \cdot 6$ \\
\hline
\end{tabular}



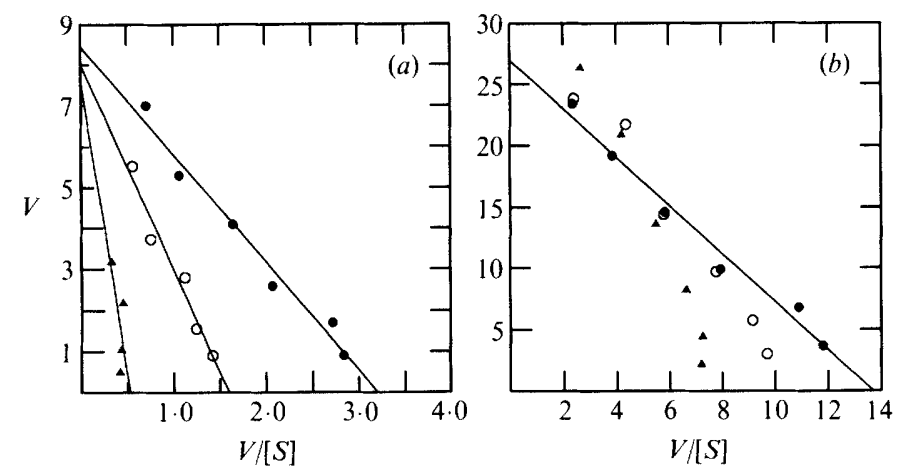

Fig. 2. Kinetics of proline and $\mathrm{T} 4 \mathrm{C}$ oxidation in membrane fractions from $E$. coli. Membranes fractions prepared from strain CSH4 (put $A^{+}$) after growth in the presence of $10 \mathrm{mM}$-L-proline were assayed as described in Methods using substrate concentrations ranging from $0.312-10 \mathrm{~mm}$. (a) EadieHofstee plot of the kinetics of proline oxidation without T4C present $(O)$, or with $1 \mathrm{mM}-\mathrm{T} 4 \mathrm{C}(\mathrm{O})$ or 3 mM-T4C $(\boldsymbol{\Delta}) .(b)$ Eadie-Hofstee plot of the kinetics of $\mathrm{T} 4 \mathrm{C}$ oxidation without proline present $(O)$, or with $1 \mathrm{~mm}$-proline $(O)$ or $3 \mathrm{~mm}$-proline $(\boldsymbol{\Delta})$. Only the regression line for no proline present is shown in $(b)$. specific activity at room temperature $\left(25^{\circ} \mathrm{C}\right)$ was $29.8 \pm$ $4.4 \mathrm{nmol} \mathrm{min}-1$ (mg protein) $)^{-1}$, or $34 \%$ of the value at $37^{\circ} \mathrm{C}$. This was comparable to the specific activity of proline dehydrogenase in these membranes [35.2 \pm $4 \cdot 1 \mathrm{nmol} \mathrm{m^{-1 }}$ (mg protein $)^{-1}$ at room temperature]. Membranes from strains JT31 (putA1::Tn5) and RM2 ( $\triangle$ putPA101) exhibited no measurable $\mathrm{T} 4 \mathrm{C}$ or proline oxidation. By contrast, membranes from strain JT34 (putP3:: Tn5) had activities similar to the wild-type.

\section{Kinetics of T4C oxidation}

The kinetics of $\mathrm{T} 4 \mathrm{C}$ and proline degradation in membranes from strain $\mathrm{CSH} 4\left(\right.$ put $\left.A^{+}\right)$were analysed. Both $\mathrm{T} 4 \mathrm{C}$ and proline oxidation activities showed simple Michaelis-Menten characteristics (Fig. 2). The mean apparent $K_{\mathrm{m}}$ value for T4C in seven similar preparations was $1.86 \pm 0.23 \mathrm{mM}$; the mean apparent $K_{\mathrm{m}}$ value for proline in four of these preparations was $2.65 \pm$ $0.98 \mathrm{~mm}$. T4C was a competitive inhibitor of proline oxidation and vice versa. In each case, the apparent $K_{\mathrm{m}}$ increased while $V_{\max }$ was not affected. Although inhibition of proline oxidation by $\mathrm{T} 4 \mathrm{C}$ showed simple competitive kinetics, the kinetics of $\mathrm{T} 4 \mathrm{C}$ oxidation were altered in the presence of proline. At low substrate concentrations, a marked deviation from linearity was noted in Eadie-Hofstee or Lineweaver-Burk plots of the data. Sigmoidicity was observed in graphs of velocity as a function of substrate concentration.

Two possible explanations for these unusual kinetics were investigated. The possibility that the results were an artifact of the T4C oxidation assay was rejected because (1) the unusual kinetics were observed in four preparations made over a period of 2 years; (2) control reactions containing proline did not have significant absorbance at $560 \mathrm{~nm}$ that might distort the results; and (3) temporal linearity in the assay was maintained even in the presence of proline. The possibility that proline might be binding to the primary proline carrier encoded by the put $P$ gene and exerting an allosteric effect on the reaction
(Wood \& Zadworny, 1979; Maloy, 1987) was also rejected. Membrane fractions from strain JT34 (putP3::Tn5) exhibited simple Michaelis-Menten kinetics for $\mathrm{T} 4 \mathrm{C}$ oxidation in the absence of proline; the $K_{\mathrm{m}}$ was the same as that in strain CSH4. In the presence of 1 or $3 \mathrm{~mm}$ proline, nonlinear but competitive kinetics again were noted.

\section{Induction of T4C and proline oxidation activities}

L-Proline is an inducer of proline dehydrogenase formation (Dendinger \& Brill, 1970; Maloy \& Roth, 1983), and membranes from strain CSH4 (put $A^{+}$) grown without $\mathrm{T} 4 \mathrm{C}$ or proline exhibited low levels of $\mathrm{T} 4 \mathrm{C}$ and proline oxidation (Table 1). To determine if $\mathrm{T} 4 \mathrm{C}$ also can induce synthesis of this enzyme, strain CSH4 was grown in minimal media containing different concentrations of either $\mathrm{T} 4 \mathrm{C}$ or proline and proline dehydrogenase activities were measured in toluene-treated whole cells (Fig. 3). At low concentrations of T4C (up to $0.5 \mathrm{~mm}$ ), the specific activities were somewhat higher than those in cultures with equivalent concentrations of proline. At higher concentrations of $\mathrm{T} 4 \mathrm{C}$, the specific activity was reduced as growth was inhibited. The highest activity was found in cultures with 1-2 mM-proline.

\section{Identification of a second T4C oxidation activity}

Although these results were consistent with the oxidation of $\mathrm{T} 4 \mathrm{C}$ by proline dehydrogenase, further experiments suggested that another enzyme might be involved in $\mathrm{T} 4 \mathrm{C}$ degradation. If proline dehydrogenase were the sole enzyme catalysing $\mathrm{T} 4 \mathrm{C}$ catabolism, strains with the putA1::Tn5 mutation should be more sensitive than wild-type strains to inhibition by $\mathrm{T} 4 \mathrm{C}$ and unable to use $\mathrm{T} 4 \mathrm{C}$ as a cysteine source. To test the first prediction, the sensitivities of strains CSH4 (putA ${ }^{+}$) and JT31 (putA1::Tn5) to T4C inhibition were compared by radial-streak assays on plates and by growth in liquid 


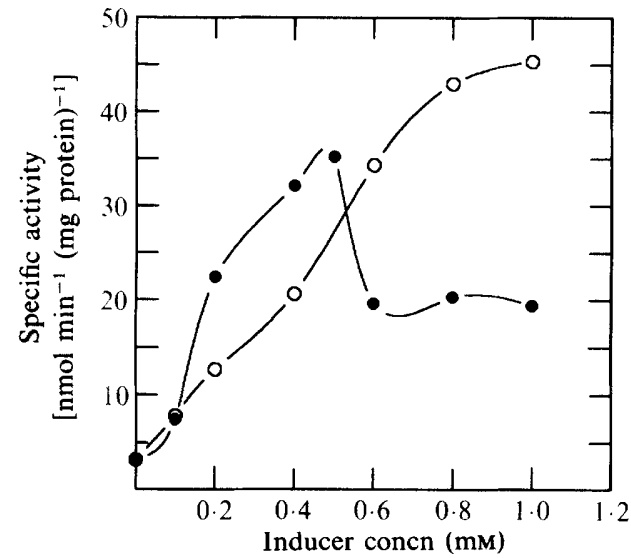

Fig. 3. Induction of proline dehydrogenase activity in $E$. coli by $\mathrm{T} 4 \mathrm{C}$ and proline. E. coli strain $\mathrm{CSH} 4\left(\right.$ put $\left.\boldsymbol{A}^{+}\right)$was grown for at least 10 generations in a series of minimal media containing $0.5 \%$ glycerol as carbon source and increasing concentrations of $\mathrm{T} 4 \mathrm{C}(\mathcal{O})$ or proline (O). Exponential-phase cells were assayed for proline dehydrogenase activity after treatment with toluene, and the specific activities plotted as a function of the initial concentration of the inducer.

Table 2. Oxygen uptake by whole cells of E. coli

Data shown are the means and standard deviations from three separate experiments.

\begin{tabular}{lcc}
\hline \hline \multirow{2}{*}{$\begin{array}{c}\text { Added } \\
\text { substrate }\end{array}$} & \multicolumn{2}{c}{ Oxygen uptake $\left[\mu \mathrm{min}^{-1}(\mathrm{mg} \text { protein })^{-1}\right]$} \\
\cline { 2 - 3 } & $\mathrm{CSH} 4\left(\right.$ putA $\left.^{+}\right)$ & JT31 $($putA1::Tn5) \\
\hline None & $19 \cdot 3 \pm 2 \cdot 8$ & $25 \cdot 5 \pm 0 \cdot 3$ \\
Proline & $115 \pm 13$ & 0 \\
T4C & $24 \cdot 6 \pm 6 \cdot 4$ & $14 \cdot 0 \pm 8 \cdot 7$ \\
\hline \hline
\end{tabular}

cultures with varying concentrations of $\mathrm{T} 4 \mathrm{C}$. When the cells were tested for T4C sensitivity after prior growth without proline, JT31 was somewhat more sensitive than strain CSH4. However, if the bacteria were tested after prior growth in $10 \mathrm{mM}$-proline, there was no difference between the strains. Because the PutA protein regulates transcription of put $P$, the greater sensitivity of JT31 in the first case appeared due to constitutive formation of the major proline carrier and increased $\mathrm{T} 4 \mathrm{C}$ uptake. To test the second prediction, the putA1::Tn 5 mutation was moved by $\mathrm{P} 1$ transduction into two $\mathrm{Cys}^{-}$auxotrophs. The resulting $\mathrm{Cys}^{-} \mathrm{Put}^{-}$strains were compared to their $\mathrm{Cys}^{-} \mathrm{Put}^{+}$parents in their use of different cysteine sources. Both Put ${ }^{+}$and $\mathrm{Put}^{-}$strains could use T4C as well as cysteine or cystine to satisfy the auxotrophic requirement.

The rates of oxygen uptake by strains $\mathrm{CSH} 4\left(p u t A^{+}\right)$ and JT31 (putAl::Tn5) were determined in the presence of proline and T4C (Table 2). The strains showed similar rates of consumption with endogenous substrates. With proline as the added substrate, strain $\mathrm{CSH} 4$ exhibited a high rate of oxygen uptake while strain JT31 showed no activity above the control level. With $\mathrm{T} 4 \mathrm{C}$ as the substrate, strain CSH4 consumed oxygen at one-quarter the rate seen with proline. Strain JT31 showed a low but significant rate of uptake which was about half that seen in strain CSH4.

\section{Discussion}

These results indicate that $\mathrm{T} 4 \mathrm{C}$ is degraded by membrane fractions from $E$. coli through a pathway similar to that in mitochondria. The initial oxidation reaction is catalysed by L-proline dehydrogenase. Whether an additional enzyme is required to convert $N$-formylcysteine to formate and cysteine is unclear. It has not been possible to synthesize 2,3-thiazoline-4-carboxylate or $\mathrm{N}$ formylcysteine and to test them as substrates. However, the spontaneous formation of cysteine in the T4C reaction mixtures suggests the hydrolysis of $\mathrm{N}$-formylcysteine is non-enzymic. T4C is also a good inducer of proline dehydrogenase synthesis. It is currently thought that addition of proline to uninduced cultures leads to reduction of the flavin cofactor in the cytoplasmic form of the PutA protein. This allows PutA to associate with the cell membrane, and as its cytoplasmic concentration drops, transcription of the putA gene increases (Maloy, 1987; Wood, 1987). The $K_{\mathrm{m}}$ for T4C is lower than that for proline, which may explain why $\mathrm{T} 4 \mathrm{C}$ is a better inducer at low concentrations.

Although Michaelis-Menten kinetics were found in reactions with single substrates, the presence of proline as a competitive inhibitor of $\mathrm{T} 4 \mathrm{C}$ oxidation led to sigmoidal kinetics. This was not a trivial property of the assay or a result of the presence of the PutP protein. In preliminary experiments with two other proline analogues, azetidine-2-carboxylate ( $3 \mathrm{~mm}$ ) had no effect on T4C oxidation, but 3,4-dehydro-L-proline ( $3 \mathrm{~mm}$ ) gave the same kinetics seen with proline. However, L-lactate ( $3 \mathrm{mM}$ ), a competitive inhibitor of purified proline dehydrogenase (Scarpulla \& Soffer, 1978), inhibited T4C oxidation in a simple competitive fashion. It is possible that another membrane-associated protein with prolinebinding sites may interact with the PutA protein and modulate its activity. Alternatively, the PutA protein may have multiple binding sites, some of which are catalytic and others regulatory. These possibilities might be distinguished by further kinetic analysis of $\mathrm{T} 4 \mathrm{C}$ oxidation by both membrane-associated and solubilized forms of the PutA protein.

Although membrane fractions from strain JT31 containing the putA1::Tn5 mutation could not convert 
T4C to cysteine, these bacteria consumed oxygen in the presence of $\mathrm{T} 4 \mathrm{C}$ at a low rate. It seems likely that there is a distinct cytoplasmic enzyme catalysing T4C oxidation. Although the assay method described in this paper would not be suitable for studying this enzyme, an alternative procedure could be developed to analyse this reaction.

These studies imply that the sensitivity of cells to T4C may be determined by the specific activity of proline dehydrogenase. The efficacy of $\mathrm{T} 4 \mathrm{C}$ as an antitumour agent or as a scavenger of reactive nitrosamines thus might be reduced in cells with high proline dehydrogenase activity, but tumour cells with reduced activity might be more sensitive to this compound. Furthermore, T4C may be a useful selective agent for studying the regulation of proline dehydrogenase synthesis in E. coli. In a genetic background in which other enzymes degrading T4C have been eliminated, mutants with an increased resistance to T4C may have elevated concentrations of proline dehydrogenase. On the other hand, bacteria that are unable to use $\mathrm{T} 4 \mathrm{C}$ as a cysteine source may have decreased amounts of this enzyme. By selecting and analysing such mutants, new insights into the control of proline dehydrogenase may be obtained.

This research was supported by a grant (R15-GM41580-01) from the National Institutes of Health.

\section{References}

Abrahamson, J. L. A., Baker, L. G., Stephenson, J. T. \& Wood, J. M. (1983). Proline dehydrogenase from Escherichia coli K12: properties of the membrane-associated enzyme. European Journal of Biochemistry 134, 77-82.

Boehler, S., Wagner, K. \& Baessler, K. H. (1989). Metabolismus der L-thiazolidinecarbonsaeure-(4). Infusiontherapie 16, 82-86.

Brugarolas, A. \& Gosalvez, M. (1980). Treatment of cancer by an inducer of reverse transformation. Lancet (January 12) 68-70.

BurT, R. J., RIDGE, B. \& RYDON, H. N. (1976). 4,4'-Bis(dimethylamino)diphenylcarbinol, a sensitive spray reagent for the detection of thiols and carboxylic acids. Journal of Chromatography 118, 240 241 .

Busiello, V., Digirolamo, M., Cini, C. \& DeMarco, C. (1979). Action of thiazolidine-2-carboxylic acid, a proline analog, on protein synthesizing systems. Biochimica et Biophysica Acta 564, 311-321.

Cavallini, D., DeMarco, C., Mondovi, B. \& Trasarti, F. (1956). Studies on the metabolism of thiazolidine carboxylic acid by rat liver homogenate. Biochimica et Biophysica Acta 22, 558-564.

CurTiss, R., III (1981). Gene transfer. In Manual of Methods for General Bacteriology, pp. 243-265. Edited by P. Gerhardt, R. G. E. Murray, R. N. Costilow, E. W. Nester, W. A. Wood, N. R. Krieg \& G. B. Phillips. Washington, DC: American Society for Microbiology.

Dendinger, S. \& BRILL, W. J. (1970). Regulation of proline degradation in Salmonella typhimurium. Journal of Bacteriology 103, 144-152.

Deutch, C. E., O'Brien, J. M., Jr. \& VanNieuwenhze, M. S. (1985). Identification of a trans-dominant mutation affecting proline dehydrogenase in Escherichia coli. Canadian Journal of Microbiology 31, 988-993.

Deutch, C. E., Hasler, J. M., Houston, R. M., Sharma, M. \& Stone, V. J. (1989). Nonspecific inhibition of proline dehydrogenase synthesis in Escherichia coli during osmotic stress. Canadian Journal of Microbiology 35, 779-785.

ELTHON, T. E. \& STEWART, C. R. (1984). Effects of the proline analogue L-thiazolidine-4-carboxylic acid on proline metabolism. Plant Physiology 74, 213-218.

Fowden, L., Lewis, D. \& Tristram, H. (1967). Toxic amino acids: their action as antimetabolites. Advances in Enzymology 29, 89-163.

GaITONDE, M. K. (1967). A spectrophotometric method for the direct determination of cysteine in the presence of other naturally occurring amino acids. Biochemical Journal 104, 627-633.

HAHN, F. E. (1980). Thiazolidine-4-carboxylic acid, a selective drug against human cancers. Naturwissenschaften 67, 307.

JOHNSON, A. B \& STRECKER, H. J. (1962). The interconversion of glutamic acid and proline. IV. The oxidation of proline by rat liver mitochondria. Journal of Biological Chemistry 237, 1876-1882.

MACKENZIE, C. G. \& HARRIS, J. (1957). $N$-Formylcysteine synthesis in mitochondria from formaldehyde and L-cysteine via thiazolidinecarboxylic acid. Journal of Biological Chemistry 227, 393-406.

MALOY, S. R. (1987). The proline utilization operon. In Escherichia coli and Salmonella typhimurium: Cellular and Molecular Biology, pp. 1513-1519. Edited by F. C. Neidhardt, J. L. Ingraham, K. B. Low, B. Magasanik, M. Schaechter \& H. E. Umbarger. Washington, DC: American Society for Microbiology.

MaLOY, S. R. \& RoTH, J. R. (1983). Regulation of proline utilization in Salmonella typhimurium: characterization of put::Mud(Ap lac) operon fusions. Journal of Bacteriology 154, 561-568.

MenZeL, R. \& RoTH, J. (1981 $a)$. Purification of the put $A$ gene product: a bifunctional membrane-bound protein from Salmonella typhimurium responsible for the two-step oxidation of proline to glutamate. Journal of Biological Chemistry 256, 9755-9761.

Menzel, R. \& RoTH, J. (1981b). Regulation of the genes for proline utilization in Salmonella typhimurium: autogenous repression by the put A gene product. Journal of Molecular Biology 148, 21-44.

Miller, J. H. (1972). Experiments in Molecular Genetics. Cold Spring Harbor, NY: Cold Spring Harbor Laboratory.

Miwa, M., Tsuda, M., Kurashima, Y., Hara, H., Tanaka, Y. \& SHINOHARA, K. (1989). Macrophage-mediated N-nitrosation of thioproline and proline. Biochemical and Biophysical Research Communications 159, 373-378.

Ostrovsky de SPICER, P., O'Brien, K. \& MaLoy, S. (1991). Regulation of proline utilization in Salmonella typhimurium: a membrane-associated dehydrogenase binds DNA in vitro. Journal of Bacteriology 173, 211-219.

PAPAS, T. \& MeHLER, A. H. (1970). Analysis of the amino acid binding to the proline transfer ribonucleic acid synthetase of Escherichia coli. Journal of Biological Chemistry 245, 1588-1595.

RATZKIN, R. \& RoTH, J. (1978). Cluster of genes controlling proline degradation in Salmonella typhimurium. Journal of Bacteriology 133, 744-754.

Rowland, I. \& TRISTRAM, H. (1975). Specificity of the Escherichia coli proline transport system. Journal of Bacteriology 123, 871-877.

SCARPulla, R. C. \& SofFer, R. L. (1978). Membrane-bound proline dehydrogenase from Escherichia coli: solubilization, purification, and characterization. Journal of Biological Chemistry 253, 5997-6001.

Tsuda, M., Frank, N., Sato, S. \& Sugimura, T. (1988). Marked increase in the urinary level of $N$-nitrosothioproline after injestion of cod with vegetables. Cancer Research 48, 4049-4052.

UNGER, L. \& DEMoss, R. D. (1966a) Action of a proline analogue, Lthiazolidine-4-carboxylate, in Escherichia coli. Journal of Bacteriology 91, 1556-1563.

UNGER, L. \& DeMoss, R. D. (1966b). Metabolism of a proline analogue, L-thiazolidine-4-carboxylate, by Escherichia coli. Journal of Bacteriology 91, 1564-1569.

WooD, J. M. (1981). Genetics of L-proline utilization in Escherichia coli. Journal of Bacteriology 146, 895-901.

WooD, J. M. (1987). Membrane association of proline dehydrogenase in Escherichia coli is redox dependent. Proceedings of the National Academy of Sciences of the United States of America 84, 373-377.

WOOD, J. M. \& ZADWORNY, D. (1979). Characterization of an inducible proline porter required for L-proline catabolism by Escherichia coli K-12. Canadian Journal of Biochemistry 57, 11911199. 